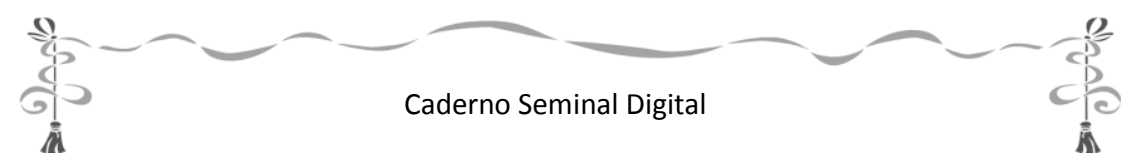

\title{
FIGURANDO EMMA BOVARY: UMA LEITURA ÍNTIMA DE SUA REPRESENTAÇÃO EM FLAUBERT E CHABROL
}

Ana Cláudia Munari Domingos*

Resumo: O texto ensaia a figuração da protagonista de Madame Bovary, de Chabrol (1991), a partir de leituras anteriores da obra de Flaubert, focalizando a concretização de Emma na comparação entre a interpretação do cineasta, para o filme, e a da leitora do livro. Tomando o procedimento da Estética da Recepção, o ensaio formaliza a representação da personagem de modo particular e através do repertório e da imaginação da leitora.

Palavras-chave: Madame Bovary; Claude Chabrol; Leitura; Concretização; Literatura comparada.

Abstract: This essay talks about the representation of the main character in Chabrol's Madame Bovary (1991), by looking into previous readings of Flaubert's book and focusing on the concretization of Emma in a comparison between the filmmaker's interpretation for the film and my interpretation as a reader. Based on the Reception Aesthetics, the text formalizes the representation of the character according to my personal impressions, considering my imagination and repertoire.

*Ana Cláudia Munari Domingos é Doutora em Letras (PUCRS, 2011), na área de Teoria da Literatura. Professora do Mestrado em Leitura e Cognição da UNISC, RS, é coordenadora do projeto Observatório da leitura na cultura digital e integra o grupo de pesquisas Intermídia no CNPq.

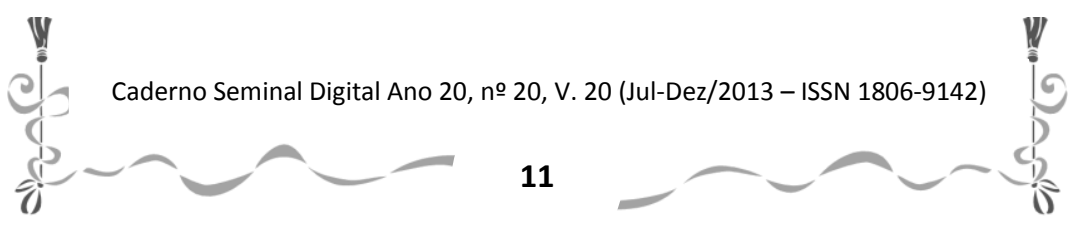


Caderno Seminal Digital

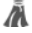

Keywords: Madame Bovary; Claude Chabrol; Reading; Concretization; Comparative literature.

A figuração da esperta aluna do convento em Rouen construiu-se em vários planos na primeira leitura do romance de Flaubert, feita por esta leitora ainda adolescente: o fascínio que a personagem nutria pela atmosfera mística das igrejas, evocada pelo cheiro, pelas imagens, pela luz incidente e pela identificação de todos aqueles objetos, ritos e cantos como expressões do belo; a rebeldia da personagem apesar de sua educação severa; e o fato de ela ser tão influenciada pela ficção quanto eu era. Assim, na primeira leitura, Emma era uma espécie de heroína do amor carnal.

A segunda leitura de Madame Bovary aconteceu durante a graduação em Letras, e a imagem de Emma não se modificou tanto assim dez anos depois: ela continuava digna de admiração em certos aspectos, apenas começava a causar certa comiseração. Já sabedora de outras interpretações e do que a crítica dizia do livro, identifiquei como sendo o bovarismo aquela ilusão que impulsionava Emma a tentar realizar na vida real os prazeres que ela alcançava através da ficção.

A imagem começava, então, a fixar-se como uma mulher ambígua, que tanto causava admiração como repúdio,

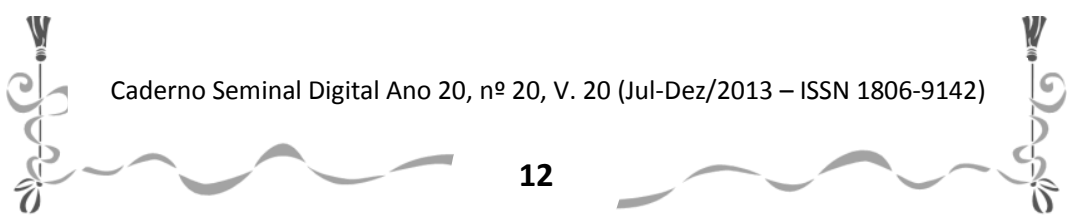


mas não deixava a esfera da ilusão, da rebeldia e da busca pela beleza e pelo prazer das coisas. A terceira leitura, feita durante o Doutorado em Letras, reforçou as cores dessa pintura. Já havia lido, então, vários outros textos em que a sociedade do século XIX era explicada, como os textos de Elaine Showalter e Andrea Nye sobre o papel da mulher na sociedade e a construção das teorias feministas, fundamentadas naquele mesmo século em que Emma ousava existir, e que hoje guiam este ensaio sobre a leitura. Naturalmente, algumas cores foram acrescidas ao painel que retratava Emma Bovary ainda como aquela moça que se deixava levar pelos castelos de sonhos dos livros.

A surpresa, então, foi assistir ao filme homônimo, adaptação da obra de Flaubert por Claude Chabrol, do ano de 1991. O problema estava em descobrir que aquela Emma das leituras não estava lá. Voltemos a essa representação, que figura Emma como uma sonhadora extremada que tenta levar a cabo a beleza e o prazer que encontra nos livros: ela é quixotesca e romântica, mas carnal e egoísta, é obstinada, mas confusa, é feminina e sedutora, mas varonil, é inteligente e tola, sedutora e ingênua. Emma Bovary é uma mulher completamente desajustada - de si e de seu tempo. Não para Chabrol. Para ele, Emma é uma alpinista social, extremamente sedutora e cínica, cujo desejo pelo prazer não tem paralelo com seu gosto pela ficção, mas é movido pela cobiça e pelo frêmito puramente carnal.

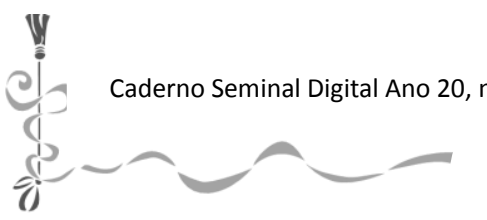

13

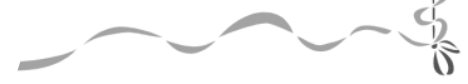


Caderno Seminal Digital

Comecemos pela figuração originalmente erguida. A história de Emma Bovary começa pela história de Charles Bovary! Ou Chabovary, como o próprio pronúncia, alguém cuja personalidade é tão oca que sequer articula o nome por inteiro, come as sílabas como se elas não fizessem falta. Mostrar a incapacidade de Charles é calcular o eixo da história, já que não podemos esquecer que, naquele século, a existência da mulher estava atrelada à existência do marido. Por tal, Chabovary vem antes, como a anunciar a tragédia: um homem incapaz de sê-lo, guenzo, incompleto, um homem que não corresponde ao papel que lhe cabe, a que tipo de mulher se associará? A uma mulher que utilizará os vazios de Charles para preenchê-los com sua própria virilidade.

Não há como negar o varão que há em Emma, já relatado por Mário Vargas Llosa (1979) em Orgia perpétua. Ela sobrepuja Charles, não apenas dirige o ambiente doméstico como as finanças do casal, cobra as contas dos pacientes e grita com ele ao jantar quando ele se deixa humilhar por um médico. Quando decide demitir a empregada, desafia Charles a impedi-la. Assim que toma Rodolphe por amante, passa a imitá-lo nos gestos, veste peças masculinas, chapéu e se deixa ser vista com um cigarro aos lábios. Emma tem plena consciência de que o corpo feminino é uma prisão - diz a Rodolphe que sequer tem a distração da aventura, quer um filho homem para desforrar-se de sua própria impotência mas é inconsciente esse frêmito varonil, que nada mais é do

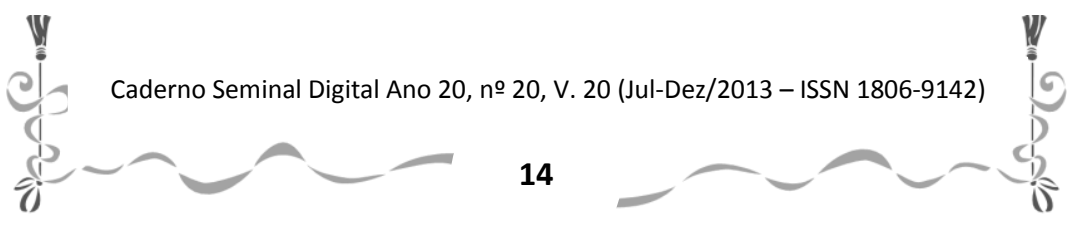


que o desejo por liberdade, essa que é uma prerrogativa exclusivamente masculina.

A primeira perspectiva de Emma na narrativa de Flaubert é dada por Charles, e coincide com uma das primeiras cenas do filme, dentro do primeiro plano, na herdade dos Bertaux, quando Charles chegando lá para curar a perna quebrada do Sr. Rouault, conhece sua filha, Emma. No livro, antes mesmo de sabermos dela mais do que seu vestido de babados, ficamos sabendo de sua capacidade doméstica pelo olhar de Charles, que o narrador, então onisciente invisível (LLOSA, 1979) acompanha: tudo é muito organizado e os metais brilham como aço polido.

É importante aqui, relacionar uma das proezas de Flaubert: a construção das imagens. Ele compunha o romance cena a cena, o scenario, que ele chamava, e em francês é o hoje conhecidíssimo roteiro. Ou seja, Flaubert compunha o roteiro de cada cena antes de redigir o texto propriamente dito, quando aí então se preocupava com a forma, com a linguagem. Nesse capítulo dois, por exemplo, em que Emma finalmente justifica o título do romance, podemos perceber quatro cenas: 1) Charles é chamado em casa para tratar Rouault, 2) parte para os Bertaux, encontra Emma na porta e entra na casa, 3) entra no quarto e faz o curativo, 4) desce à sala para beber e conversa com Emma, em dois planos, pois sobe novamente para despedir-se do velho, mas o narrador não o acompanha, e volta onde está Emma, partindo

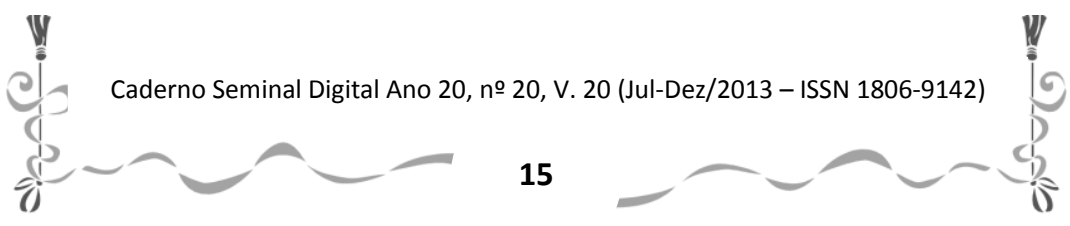


Caderno Seminal Digital

î.

novamente. Depois, o capítulo prossegue com o narrador resumindo o tempo circular, em que as ações se repetiram até o episódio em no qual voltando o tempo singular (LLOSA, 1979) relata a ruína de Heloise, esposa de Charles, e que culmina na sua morte.

Flaubert, enfim, facilitou para Chabrol, pois ele mesmo dividia os capítulos em planos e cenas. Para o mesmo capítulo adaptado para o filme, há também quatro cenas, com algumas diferenças. A primeira cena do capítulo dois é excluída, já que Chabrol optou por não incluir o primeiro casamento de Charles, apenas sua viuvez é mencionada, e sequer podemos ter certeza de que Heloise ainda estava viva na ocasião do primeiro encontro entre Charles e Emma. A primeira cena do filme, então, mostra Charles já no caminho dos Bertaux; no entanto, diferentemente do livro, Charles sobe as escadas logo em seguida e não tem tempo para observar a casa e perceber as prendas de Emma. Aí, já se conforma uma diferença na figuração da personagem, o que prossegue na cena seguinte. O corte da cena, no livro, acontece quando, dentro da casa, o narrador muda o foco de atenção para o que Charles vê, o que no filme só acontece quando ele já está no quarto examinando o pai de Emma.

A segunda cena, assim, se passa no quarto, tal como no livro, em vários planos, com um diferencial muito importante: há um corte que, embora pareça apenas uma mudança de plano da cama do doente para Emma sentada, há a percepção

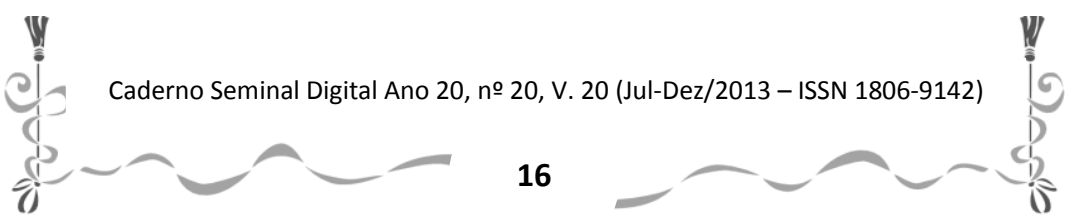


Caderno Seminal Digital

de que transcorreu certo espaço de tempo também, já que Emma está costurando as almofadas para o aparelho da perna do doente, como se Ihe havia sido pedido. Tal corte tem um significado: mudar o foco de sentido para que Emma possa ser posta em quadro no exato momento em que põe o dedo na boca para chupar o sangue que escorre da picada da agulha. Esse plano é fundamental na composição da personagem, porque a mostra extremamente sensual, correspondendo ao olhar de Charles. Embora pareça que, a princípio, seu olhar é ingênuo, por uma breve fração de segundos ele se transforma ao encarar Charles, mostrando que ela adquire a consciência do seu gesto.

No livro, essa cena ocorre em tempo quase circular, repetidamente Emma pica os dedos e os leva à boca, porque tem pressa de terminar a almofada para que Charles possa colocá-la em Roualt. Nunca encarou Charles durante esse gesto, nem ele pareceu ter dado atenção a ele. Conhecendo Flaubert, sabemos que essa cena também configura certo erotismo - se está lá, tem um sentido determinado -, mas o gesto de Emma demonstra um automatismo pela repetição. No filme, o quadro com Emma em primeiro plano, figura uma mulher sensual e consciente do seu poder de sedução. É um plano marcado, extremamente significativo, que define a sintaxe da personagem, como veremos.

A última cena mostra Charles partindo; a diferença entre esta e a do livro é que Chabrol optou por incluir agora

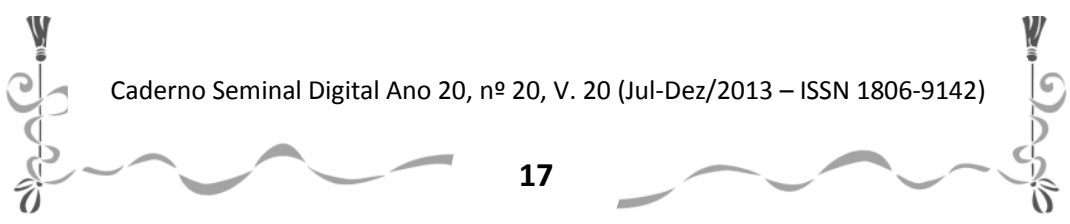


Caderno Seminal Digital

Aิ

uma característica de Charles: a pronúncia afobada do nome, que ele repete para Emma na saída. As digressões do narrador são omitidas por necessidade, já que falam da ruína e da morte de Heloise, detalhes que não fazem parte do filme. 0 capítulo seguinte, portanto, tem início igual para ambas narrativas, quando Rouault vai visitar Charles para pagá-lo.

O fato de Flaubert segmentar sua narrativa em cenas bem definidas permitiu a Chabrol escolher os elos significativos do filme, por isso, a adaptação da fábula é fiel, ou seja, o filme não transgride a primeira camada da obra, comunica a história. Pedindo emprestada a moral do livro, cunhada pelo próprio Flaubert para a sua defesa no julgamento em que é acusado de imoralidade - mostrar os riscos que envolvem o fato de uma mulher receber educação superior à classe a que pertence -, verificamos, no entanto, que provavelmente aquele espectador do filme que não foi um leitor do livro não sintetize dessa maneira a película. A educação de Emma e os anos no convento não estão aí evidenciados, nem a sua avidez pela leitura.

É justamente nesse ponto que o paralelo entre as narrativas - literária e fílmica - começa a se alargar, distanciando-se, mas sempre tomando o mesmo rumo: o destino trágico de Emma. As causas desse destino, na primeira, têm relação com aquilo que, mais tarde, tomou o nome da protagonista, o bovarismo; na segunda, relaciona-se com a ambição de Emma e sua busca por prazer. No livro, esse

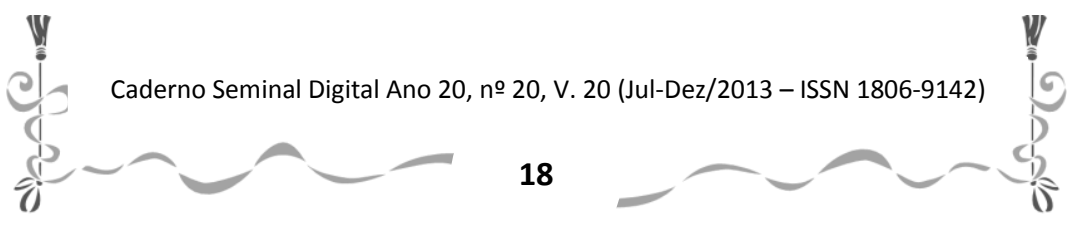


desejo é catapultado pela fiç̧ão, pela ilusão, e a tragédia se faz pela impossibilidade de a vida imitar a Arte. No filme, o desejo é puramente carnal e humano, e o final é uma consequência do egocentrismo de Emma.

Na película, a sintaxe da personagem é construída pela sedução. No episódio seguinte, por exemplo, o Sr. Rouault vai até a casa de Charles para levar o pagamento e o convida a visitá-lo novamente. No livro e no filme, ambos conversam sobre a viuvez do agente de saúde; no primeiro, ela ocorreu depois de Charles ter curado a perna do velho, alguns meses depois que ele parou de visitá-los, por insistência de Heloise; no filme, a viuvez parece ter ocorrido antes, já que Rouault comenta que Charles "também é viúvo". A diferença marcante, no entanto, está no convite de Rouault: no livro, ele sugere que Charles vá visitá-los para se distrair. O comentário de que Emma pergunta por ele e reclama que a esqueceu está presente aí e no filme, mas, nesse, a sugestão do pai de Emma é bem explícita, pois, segurando um copo com bebida, e sorrindo, ele diz a Charles que eles farão tudo para distraí-lo, piscando em seguida e sorvendo todo o líquido. 0 sorriso, o olhar, a piscada, o gesto de beber com vontade, tudo sugere mais do que a distração das caçadas, proposta no livro.

A próxima cena de sedução vem a seguir. Embora ocorra em ambas narrativas, no livro, é sutil, e no filme, explícita. Por causa dos princípios morais da época, certamente Flaubert procurou colocar um véu sobre a

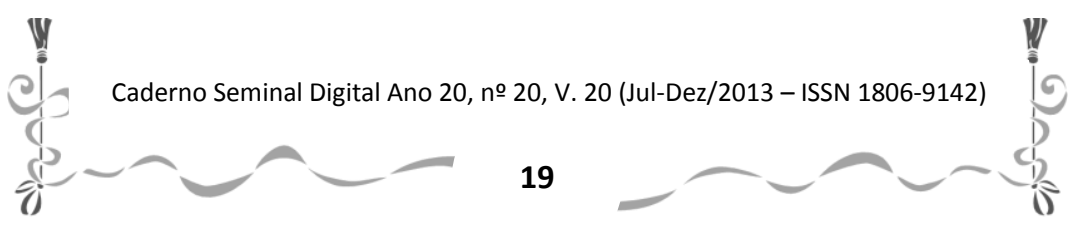


Caderno Seminal Digital

î

sexualidade de Emma, mas ainda assim ela é um dos temas do romance, extremamente importante para o contexto da moral que ele deseja transmitir. No filme, esse véu é despido naquelas ocasiões em que isso é possível sem que se desvirtue esse ambiente de sexualidade velada. É o caso do episódio da visita de Charles aos Bertaux, logo a seguir do convite do velho Rouault.

No livro e no filme, a cena inicia da mesma forma, Charles entrando na casa e vendo Emma costurando, embora, no livro, ele não a perceba de imediato. Na narrativa literária, Emma logo oferece uma bebida, porque é costume no campo, justifica o narrador. No filme, ela o convida a beber com ela. Em ambos os_casos, Charles recusa, mas Emma ignora-o e serve a bebida. No livro, entretanto, Emma insiste e sugere, então, que tome um licor com ela, sorrindo. No filme, Ela apenas diz "vamos beber" e se ergue para servir a bebida. A cena a seguir é a mesma nas duas narrativas: Emma serve a bebida, eles tomam, e ela senta-se para prosseguir com a costura. Ao beber, Emma vira bem o copo, erguendo a cabeça, e coloca a língua no fundo para sorver as últimas gotas. A diferença está presente em dois pontos: primeiro, no livro, o narrador justifica o gesto de Emma, informando que ela serviu um copo até a borda e um pouquinho no outro (o dela), o que não ocorre no filme, pois não a vemos servir; segundo, no filme, eles estão bem próximos, e Emma olha para ele antes de pôr a língua no fundo do copo, mexendo-a para lamber a

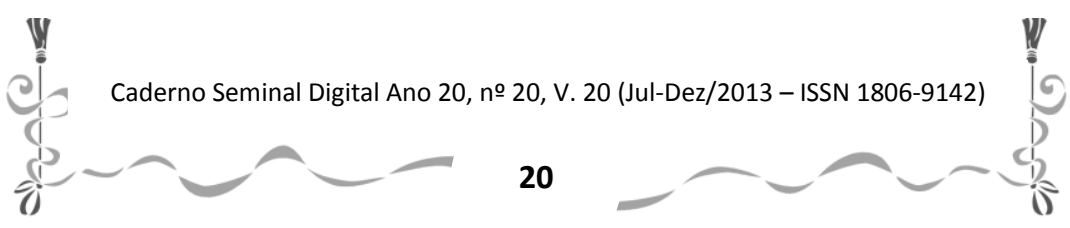


Caderno Seminal Digital

证

bebida; quando percebe que foi vista por Charles, sorri. A cena é extremamente erótica. A sugestão do livro é aí sublimada: o encostar o copo um no outro, como um brinde, no livro, sugere certa proximidade, que, no filme, é levada ao limite. Também o gesto de Emma de pôr as mãos na face para aliviar o calor é feito enquanto Charles, em pé à sua frente, observaa diretamente. No livro, nada garante que Charles tenha enxergado o gesto, pois ele está observando o vento arrastar a poeira pelo sobrado.

Em seguida, no livro, em um parágrafo, o narrador conta que Emma queixa-se de tonturas a Charles, perguntaIhe se banhos de mar seriam bons para combatê-la; depois, Emma fala do convento, e Charles do colégio. A expressão do narrador "as frases se seguiram" sugere que eles conversaram mais sobre esse assunto, o que dá margem à exploração de Chabrol. A seguir, ela lhe mostra os livros e a coroa de louros que ganhara como prêmios e seu caderno de música, fala de sua mãe e mostra o jardim onde colhe flores para levar ao túmulo.

No filme, quando se queixa de tonturas, Emma conta a Charles que fingia desmaiar no convento, para que fosse mimada pelas freiras. Emma conta a ele que é capaz de fingir piripaques para receber atenção - e ela acabou de falar em tonturas! Depois, Emma vai pegá-lo pela mão, levando-o a um ambiente que parece ser seu quarto (!), pois mexe numa cômoda onde suas coisas estão guardadas, para lhe mostrar

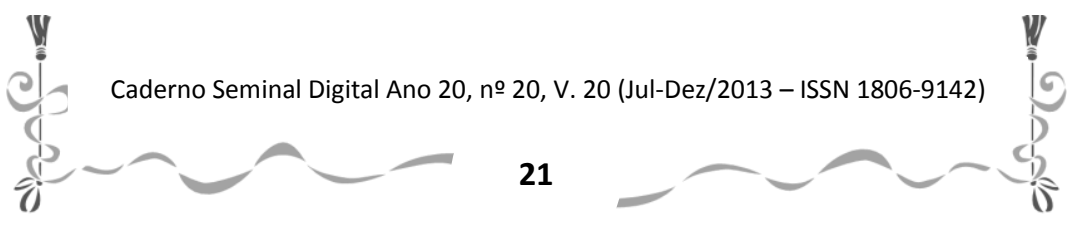


Caderno Seminal Digital

Â

aqueles mesmos objetos citados no livro: os cadernos de música - e acrescenta que ama a música, mas as aulas eram tediosas - e os prêmios; a coroa de louro ela põe na cabeça, enquanto diz que a mãe orgulhava-se dela. Não mostra o jardim, apenas fala das flores, enquanto sua expressão se entristece e ela passa a olhar pela janela, falando que gostaria de morar na cidade, pelo menos no inverno, apesar de os dias de verão serem ainda mais tediosos. E, virando-se para Charles, pergunta-Ihe se ele não concorda. Corte.

No livro, enquanto fala, a expressão e o tom de voz de Emma vão-se modificando, e o pensamento dela parece vagar. Tem-se aí a nítida impressão de que ela está sonhando com as cidades dos livros, outros lugares, por isso a languidez, a expressão aérea. No filme, Emma nitidamente parece implorar para que Charles a tire de lá: faz propaganda de si mesma, diz que a mãe orgulhava-se dela, diz que quer morar na cidade, mas não sugere nenhum motivo além da aparente tristeza. Charles cai na rede: a cena seguinte, como a confirmar que foi seduzido, é o episódio em que Charles tenta pedi-la em casamento, e recebe a aprovação do pai de Emma mesmo sem conseguir pronunciar a famosa frase. No livro, entre essas cenas, há as digressões de Charles e Rouault sobre um provável pedido.

Emma já se torna Madame Bovary, uma moça que finge desmaios para receber atenção e sabe seduzir com discrição. O filme prossegue nessa representação. A próxima

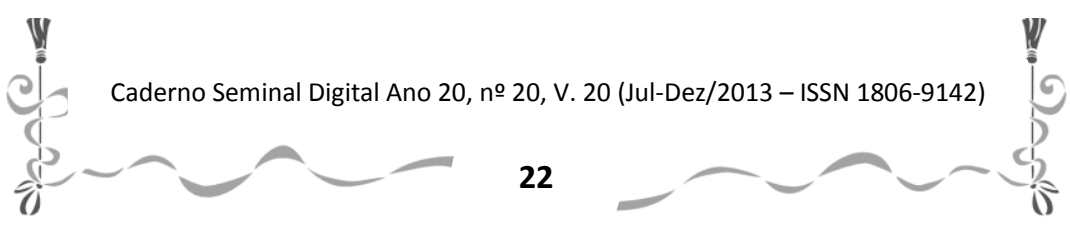


Caderno Seminal Digital

Â

cena a destacar é a da noite de núpcias, que, no livro, não é narrada e ocorre na casa de Rouault; apenas há o comentário de que Emma pediu para ser poupada das brincadeiras, e que um primo tentou, mesmo assim, atirar água pela fechadura. No dia seguinte, no entanto, Charles parecia outro homem, se durante a boda estava introvertido, agora, exultava. Conforme o narrador, ele é quem parecia o virgem da véspera, enquanto a expressão de Emma nada dizia sobre suas emoções.

No filme, a sedutora Emma entra de penhoar no quarto, já na casa de Charles, e caminha até ele, que, parado em pé, espera por ela. É ela quem se aproxima dele para consumar o casamento. Antes, ao chegar à casa, ela já tinha dito que não estava com fome, nem queria conhecer o consultório, pois queria deitar-se, e fala aproximando-se de Charles. O comportamento de Charles, no dia seguinte, é o mesmo: alegria. No filme, entretanto, isso está exacerbado: Charles sai do quarto todo desgrenhado, com a camisa para fora das calças, de sorriso largo, gritando para a empregada que eles estão com fome, quer novidades, coisas que não está acostumado a comer no café. Emma, séria, suave, aceita qualquer coisa, a sopa que Nastasie preparou está bem. A diferença, no filme, também está no gesto de Emma após a saída de Charles, nesse primeiro dia de casados, o que não está presente no livro, pois eles só vão para casa dois dias depois do matrimônio. Quando Charles sai com a charrete, erguendo o chapéu para Emma, ela sorri da porta. Assim que

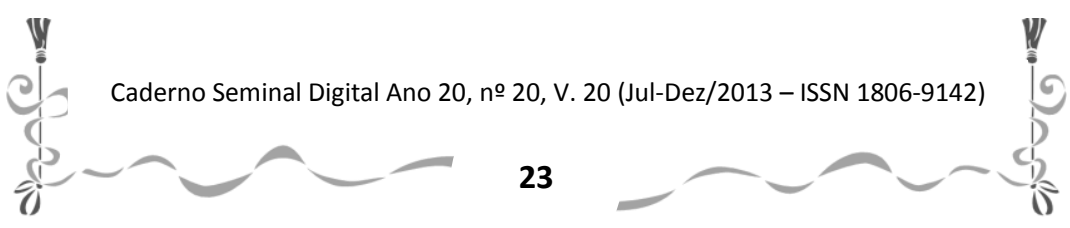


Caderno Seminal Digital

ele se afasta, sua expressão se torna séria, ela passa os olhos pela rua, e fecha a porta com força. Parece desde já decepcionada com tudo.

Realmente, o tédio se impõe na vida doméstica de Emma. No filme, isso é transmitido pela consecução das três cenas seguintes: Emma toca piano, para, suspira, começa a anotar a canção; em seguida, passeia sozinha por uma estrada; Charles chega, à noite, e ela reclama que ele tem chegado cada dia mais tarde - e assim sabe-se que a vida de Emma não passa disso, nada de importante, diferente, ocorreu-lhe.

No livro, antes disso, há um capítulo em que essa passagem de tempo sugere a felicidade de Charles, cada vez mais apaixonado e satisfeito com o casamento: nada lhe falta, tem o coração transbordando dos prazeres da noite, sua existência gira em torno da circunferência das saias de Emma. A descrição das alegrias de Charles com o casamento durante todo esse capítulo existe em contraposição ao último parágrafo, em que o tédio de Emma começa a se configurar. $\mathrm{Se}$, no filme, entretanto, esse tédio surge da rotina, no livro, é diferente. Ali, Emma está frustrada porque não consegue encontrar na vida real aquelas emoções que nos livros pareciam tão bonitas.

No próximo capítulo, é-nos apresentada a essência de Emma, como a confirmar a frustração: a leitora de Paulo $e$ Virgínia, que sonhava com uma cabana de bambus e sujava as

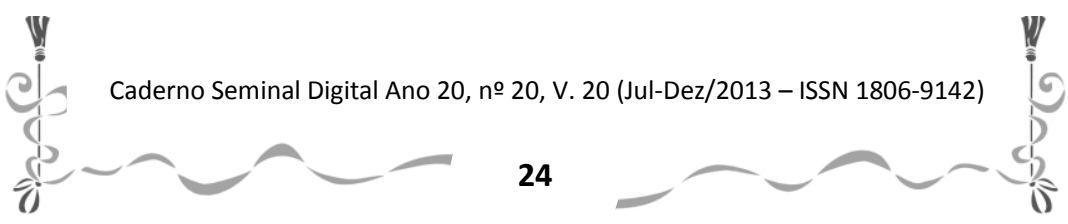


Caderno Seminal Digital

mãos de pó nos gabinetes de leitura, que admirava as heroínas infelizes, Joana D'Arc, Heloísa, Inês Sorel; a menina que se encantava com o ambiente místico da igreja e preferia contemplar as vinhetas dos livros, as imagens e os quadros durante a Missa; a moça cujo temperamento era mais sentimental que artístico, que ficou satisfeita quando ficou pálida e doente como as heroínas dos livros, quando a mãe morreu. 0 narrador conta a sequência de frustrações de Emma, tudo lhe cansa com o tempo, assim como se aborreceu do convento e depois do campo, quando voltou para casa, assim como já não compreendia que a expectativa do casamento tenha se tornado essa tranquilidade que a enfastiava.

No filme, em seguida ao gesto de arrumar um quadro e bordar uma tela, Emma pergunta-se por que se casara. O que Ihe incomoda é a rotina, e nada sugere que ela pudesse ter outras expectativas por causa dos muitos romances que leu e por todas as ilusões que criou sobre a vida. No livro, essa pergunta vem um pouco depois, quando, no capítulo seguinte, nova contraposição é erguida entre a felicidade de Charles, que nada mais espera da vida, e Emma, que não encontra nada do que deseja. A tranquilidade de Charles a irrita, percebe que ele está muito distante dos príncipes e heróis dos romances, como as cidades, como os castelos. Nada disso se faz presente no filme, e essa Emma acaba por se revelar uma mal-agradecida, alguém a quem falta um trabalho, algo produtivo a fazer.

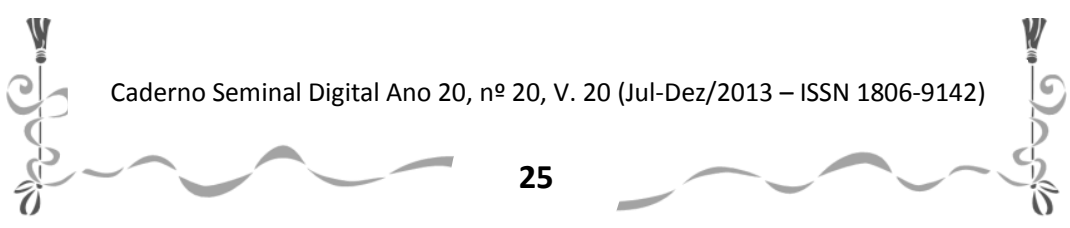


Caderno Seminal Digital

Em Tostes, o papel de Emma estava ainda mais definido do que no campo. Lá, embora as mulheres trabalhassem também junto aos homens, o pai de Emma resolvera afastá-la das lides agrícolas pela educação esmerada que ela recebera no convento. $\mathrm{Na}$ cidade, o espaço estava bem demarcado entre o público e o privado, cabendo às mulheres o papel restrito ao lar. Ali, elas eram necessárias para organizar o funcionamento da casa, proteger e educar os filhos - seguindo o mesmo modelo em que estavam inseridas - e receber as pessoas promovendo a inclusão do marido na esfera pública. Reclusas à esfera privada, sob os olhos do marido, do padre e do médico, garantia-se, assim, a hereditariedade e a conservação dos bens naquele núcleo familiar, já que era necessário não apenas a certeza da fidelidade, como também a educação dos filhos para a continuidade do sistema, interessante a todas as instâncias dominantes naquele século XIX não tão distante.

Apesar de realmente só dispor, e utilizar-se do meio do casamento, Emma transgride o papel que deveria caber-lhe em vários sentidos. Não tem a presença da mãe, para lhe transmitir os termos de sua conduta; o marido e o médico são a mesma pessoa e, como vimos, incapaz de exercer o papel que, por oposição, forçaria Emma a revestir-se do seu; o padre não dá atenção a Emma quando ela a ele recorre, pois considera que as necessidades do corpo urgem mais que as do espírito - há mulheres com fome e com frio.

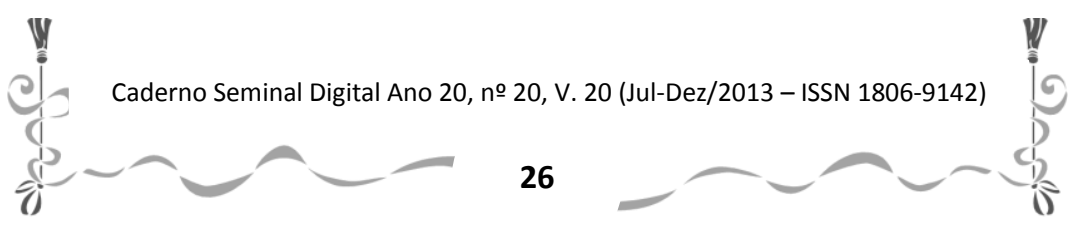


Caderno Seminal Digital

O papel feminino conforma-se às classes sociais, inclusive alcançando certos direitos de acordo com a posição social, caso de Emma, que dispunha de governanta e de ama de leite. Sobra-lhe tempo para bordar, pintar, tocar piano e fazer fuxicos. Mas Emma não tem pares nessa sociedade, ela está deslocada, como fica evidente na observação do farmacêutico, Sr. Romais, para quem Emma ficaria muito bem numa subprefeitura. Prefere conversar com os homens, mas até o próprio marido tem uma conversa que ela considera plana demais e, assim, faltam-Ihe companhias. Se Emma fosse uma nobre, seu destino seria completamente diferente. Tanto no livro quanto no filme, podemos perceber o quanto ela observa e admira a vida de luxo, champagne, valsas e amores. Ao perceber, por exemplo, a entrega furtiva de um bilhete por certa senhorita a um cavalheiro, Emma inclui o adultério no rol dos acontecimentos admiráveis e prazerosos da nobreza a que ela tanto almeja.

No episódio do baile, uma cena excluída no filme contribui na figuração de uma personagem diferente da Emma Bovary de minha concretização. É a cena em que Emma percebe os camponeses observando o baile através da vidraça. Ali, ela volta-se ao passado para renegá-lo - quase não acredita que possa ter vivido no campo e ter feito parte daquela sociedade do lado de fora -, pois se sente inserida na casa, como parte do grupo que dança ao som da orquestra e toma sorvete de marasquino, e ela fecha os olhos, absorvida,

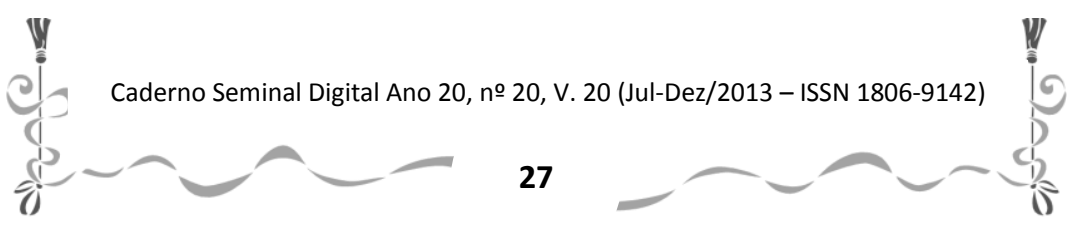


Caderno Seminal Digital

î.

como se estivesse finalmente dentro de um romance, o resto é sombra.

A charuteira verde encontrada por Charles é outro detalhe que altera a personificação de Emma. Sempre que o tédio toma conta de si, Emma vai até ela, como um modo de fazer voltar àquela atmosfera do baile, através da excitação dos sentidos. Nesse objeto-fetiche, substituto mais forte que o livro, pois traz recordações reais, Emma sente o hálito do amor, vê a figura do Visconde em Paris, transgredindo o próprio espaço do baile. Seu pensamento atravessa as ruas da cidade-luz, e ela compra um mapa e assina jornais de senhoras. Novas leituras entram na vida de Emma para dar conta dessa nova experiência: Eugène Sue, Balzac e George Sand. Durante as leituras, ela concretiza a imagem do Marquês, agora um de seus heróis, e compara a figura do marido aos personagens inventados.

Nesse ponto, o narrador é pródigo em nos avisar da confusão que Emma faz entre ficção e realidade: o pensamento de Madame Bovary afasta-se das coisas reais para se realizar no sonho, e ela confunde os hábitos da classe superior - o luxo, a ostentação - com a felicidade e o prazer de viver. Tudo isso está distante da Emma do filme, à medida que, aí, não é da ficção que Emma extrai seu afã, corroborado pelo baile, mas seu desejo emana apenas do próprio acontecimento do baile, e apenas pela vontade de pertencer àquela classe social. A irritação e o desprezo que Emma passa

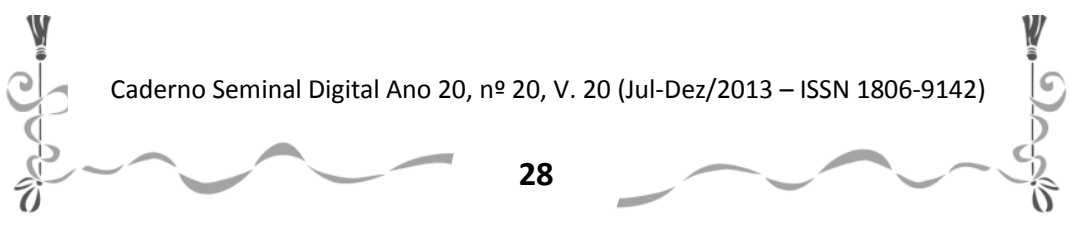


Caderno Seminal Digital

a sentir pelo marido também são modificados no filme. No livro, Emma irrita-se com ele porque ele não corresponde em nada ao ideal de marido que ela desejava. Quando cuida dele, arruma sua camisa, ou põe fora suas luvas velhas, é por puro egoísmo, diz-nos o narrador, é para não sentir vergonha dele diante da sociedade. O episódio da cirurgia no pé de Hipolyte mostra, no livro, que a intenção de Emma é fazer de Charles esse personagem que ela deseja para sua história; no filme, parece que ela quer apenas a fama do marido e as consequências econômico-sociais dessa fama.

Um dos poucos momentos em que, no filme, é demonstrado o fascínio que a literatura exerce sobre Emma é na ocasião em que ela conhece Leon, episódio que coincide com o livro. O gosto pela literatura é o elo entre os futuros amantes, mas é no livro que Emma dá indicações sobre o que Ihe atrai em suas leituras: histórias curtas e que provoquem medo. Mas seu gosto é volátil: detesta que as coisas sejam apresentadas, na literatura, tal como são na vida - os heróis comuns e os sentimentos moderados. Logo em seguida, o narrador comenta que a cada vez que ela dormia em algum lugar diferente, apostava aí todas as fichas numa mudança na sua vida, como a mudança para Yonville, proposta por Charles na esperança de modificar o humor da esposa abatida.

Ao planejar uma fuga com o amante Rodolphe, ela se imagina elevando-se com ele pelas nuvens; seus sonhos ultrapassam os mapas, as ruas, inexistem como concretização

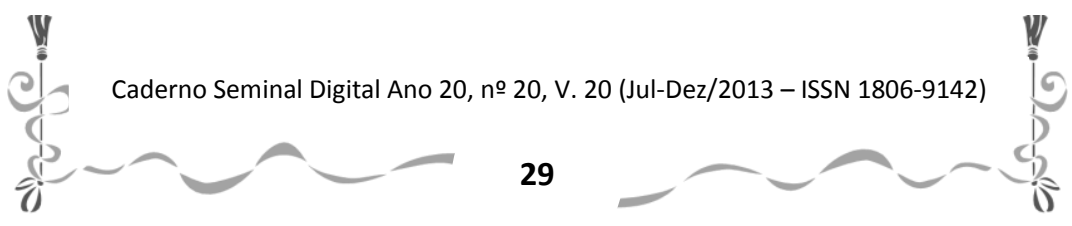


Caderno Seminal Digital

î.

real. Em Chabrol, apenas a frase é a mesma - eu tenho um amante -, mas não o sentimento de Emma, provocado pela sensação de que finalmente ela estava conseguindo realizar seus sonhos ficcionais. $E$, mesmo quando percebe que estava enganada, mostra-se consciente de que criara um mundo de ilusões, cujo infortúnio não tem razões na realidade. O motivo de Emma tornar a ser uma esposa dedicada fica em suspenso ali. Já, no livro, há uma cena em que as razões para a dedicação de Emma ao marido, à filha e à casa, tornam-se bem claras. Logo depois da visita do Sr. Lhereux, Emma recusa-se a comprar qualquer coisa dele, mesmo gostando muito de um xale. No livro e no filme, a frase é a mesma como fui ajuizada -, mas a cena é diferente: no primeiro, Emma fala para si, depois de refletir, ao jantar, sobre o fato e lembrar o belo xale. No filme, em seguida à saída do vendedor, ela mira-se no espelho, altiva, e pronuncia a frase, como a admirar a sua própria personagem, a sua mise-enscène. Entra Leon e ela pega o primeiro bordado da pilha para fingir que borda - comprovando a construção de uma personagem - e recebe-o com frieza.

O que se segue é diferente nas duas narrativas. No filme, logo depois da cena com Leon, o narrador passa a comentar a dedicação de Emma, numa sequência de cenas que comprovam a boa esposa que ela se tornou: tira as botas de Charles, coloca-Ihe chinelos aquecidos na lareira, cuida de Berthe, exibindo-a às visitas. No livro, Leon está presente em

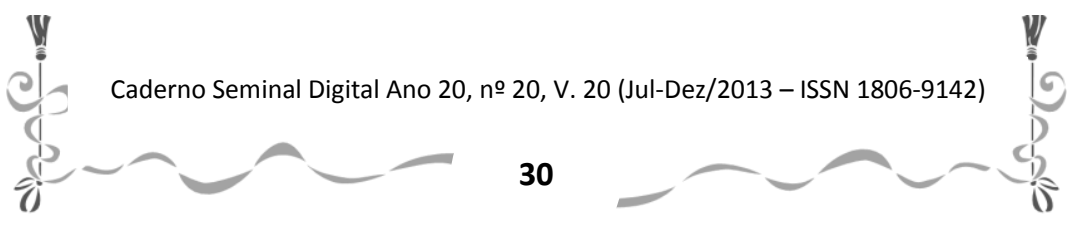


Caderno Seminal Digital

Â

uma dessas cenas, em que observa Charles, sentado, satisfeito e feliz, bem alimentado e aquecido em frente à lareira, recebendo um beijo de Emma. Leon exaspera-se, percebe-a perfeita, inatingível, abandonam-lhe as esperanças de possuíla. Ora, Emma acaba de fazer dele um herói romântico, confirmando-se como a heroína que ela almejava ser.

Confirma essa hipótese o fato de que, no seguimento, Emma empalidece, emagrece, e se torna um modelo admirado pela comunidade. Ela deseja Leon, mas prefere a solidão, para imaginá-lo em sonhos, e espera por uma catástrofe que mude o rumo dos acontecimentos. Emma quer uma vida romanesca, uma tragédia, um romance impossível, um marido traído, uma paixão que transgrida o tédio da vida real.

No filme, a cena final da mulher bem comportada é na cama, quando Emma corresponde à iniciativa de Charles e curva-se para ele. A cena seguinte corresponde a do livro, quando Emma chora e é consolada por Felicitè. A montagem, que põe em sequência a cena da cama e a do sofrimento de Emma, leva o espectador a colocar a frustração dela no plano sexual, coisa que se evidencia também no livro. Mas a falta de toda essa relação entre o imaginário de Emma e seu desespero desaparece no filme, pondo em evidência apenas o plano carnal - luxúria, sexo, aventura - situação que, no livro, é bem mais complexa.

As aflições de Emma Bovary, personagem de Gustave

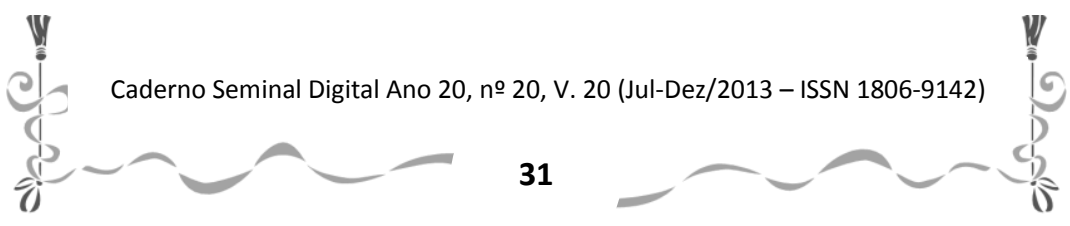


Flaubert, não correspondem apenas ao seu desapontamento com Charles e seu desamor por ele, à falta de paixão, à decepção sexual, mas ao confronto que ela faz entre a vida que desejava, baseada na ficção, e a vida que leva. $O$ encontro com o padre só vem a confirmar que há algo mais imaterial por trás daquele inexplicável mal-estar. Emma procura-o porquê quer entender o que se passa com ela, aquela constante insatisfação, mas ele não entende bem as aflições espirituais de Emma, está mais preocupado com os males do corpo de sua congregação ou com os deveres práticos de sua profissão. Felicitè estranha o comportamento de Emma, porque os casos que ela conhece foram curados pelo casamento. Para as mulheres, o casamento é a solução, a cura dos males, a segurança. Não para Emma, ela é diferente. Flaubert, que a princípio transgride o pensamento vigente da fragilidade da mulher, da sua sensibilidade, do seu peculiar sistema nervoso (!) - acaba por corroborar a idéia de que, ao abandonar o papel que lhe cabe, a mulher leva a si própria e à sua família à tragédia.

No livro, quando a mãe de Charles percebe o desvirtuamento dessa função, logo proíbe Emma de ler romances. Ela bem sabe que é preciso sufocar esses desejos, que a realidade deve ser aceita a qualquer custo, sob a ameaça da perdição da família. No filme, os livros ficaram para trás, nos comentários entre Emma e Leon. E toda a sequência de Emma rumo ao desastre é um caminho frenético da busca

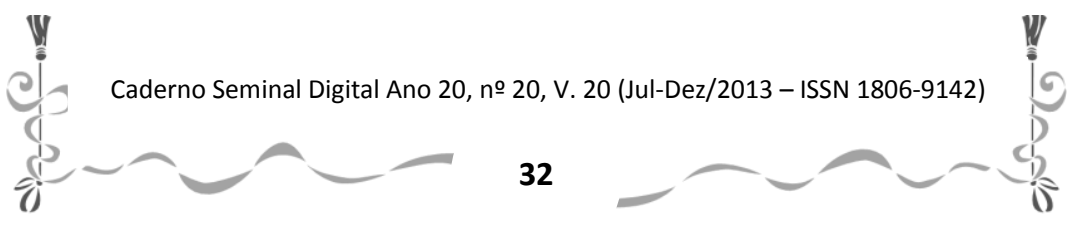


do prazer pelo prazer: primeiro Rodolphe, que não a leva para Paris, cidade de seus sonhos, depois Leon, que aí não é a tentativa de resgatar aquele herói de outrora, mas apenas o possível pela oportunidade que o próprio Charles oferece. Entremeados pelos amantes, estão os objetos de prazer, que ela adquire mais e mais, para recriar aquela atmosfera do baile. No livro, o que se percebe claramente é que o amor, a paixão e o sexo não a satisfazem puramente, precisa recriar o ambiente romanesco: luxo, tapetes, cortinas, berloques, porcelanas, jarras, retira-os todos da fiç̧ão. Quer criar seu próprio scenario.

A Madame Bovary de Chabrol está completa, sua figuração foi regida pela sintaxe da sedução, da luxúria, da ambição. É uma mulher frustrada porque quer riqueza e amor, luxo e paixão. Seu fim trágico, traçado tal e qual o do livro, é o mesmo que lhe dá Flaubert, porque não há outro destino para Emma, para quem a humilhação e a ruína são impensáveis. No livro, Emma Bovary prefere morrer como suas heroínas, sofrendo, ainda amada e admirada, sob lamúrias e penas de seu séquito. E essa é a Madame Bovary que eu concretizei como leitora, pesquisadora e crítica, em três leituras: a Emma do bovarismo, precursora, de quem já se disse tudo e sobre quem sempre haverá muito a dizer.
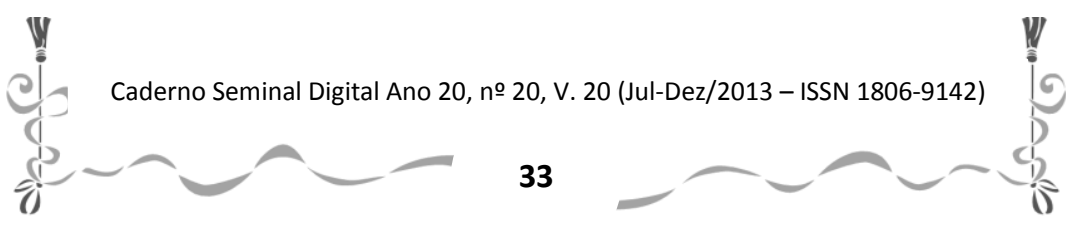


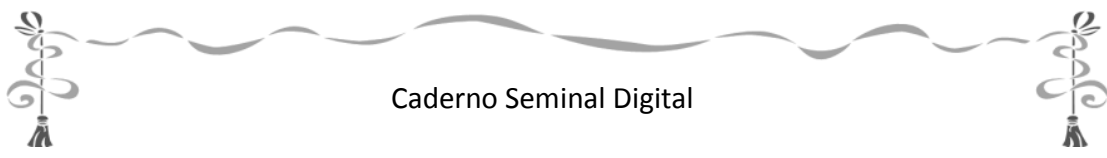

\section{REFERÊNCIAS BIBLIOGRÁFICAS:}

CHABROL, Claude. Madame Bovary. França, 1991.

FLAUBERT, Gustave. Madame Bovary. Porto Alegre: LPM, 2003.

LLOSA, Mario Vargas. Orgia perpétua: Flaubert e Madame Bovary. Rio de Janeiro: F. Alves, 1979.

NYE, Andréa. Teoria feminista e as filosofias do homem. Rio de Janeiro: Record: Rosa dos Tempos, 1995.

SHOWALTER, Elaine. Anarquia sexual: sexo e cultura no fin de siècle. Rio de Janeiro: Rocco, 1993. 